\title{
ORIGINAL ARTICLE \\ Kinetics of the inhibition of renin and angiotensin l-converting enzyme by cod (Gadus morhua) protein hydrolysates and their antihypertensive effects in spontaneously hypertensive rats
}

\author{
Abraham T. Girgih 1,2, Ifeanyi D. Nwachukwu ${ }^{1,2}$, Fida Hasan ${ }^{3}$, Tayo N. Fagbemi ${ }^{4}$, Tom Gill ${ }^{3}$ \\ and Rotimi E. Aluko ${ }^{1,2} *$
}

'Department of Human Nutritional Sciences, University of Manitoba, Winnipeg, Canada; ${ }^{2}$ The Richardson Centre for Functional Foods and Nutraceuticals, University of Manitoba, Winnipeg, Canada; ${ }^{3}$ Department of Process Engineering and Applied Science, Dalhousie University, Halifax, Canada; ${ }^{4}$ Department of Food Science and Technology, Federal University of Technology, Akure, Nigeria

Abstract

Background: Cod muscle has a balanced protein profile that contains potentially bioactive amino acid sequences. However, there is limited information on release of these peptides from the parent proteins and their ability to modulate mammalian blood pressure.

Objective: The aim of this study was to generate cod antihypertensive peptides with potent in vitro inhibitory effects against angiotensin-converting enzyme (ACE) and renin. The most active peptides were then tested for systolic blood pressure (SBP)-reducing ability in spontaneously hypertensive rats (SHRs).

Design: Cod protein hydrolysate $(\mathrm{CPH})$ was produced by subjecting the muscle proteins to proteolysis first by pepsin and followed by trypsin + chymotrypsin combination. In order to enhance peptide activity, the CPH was subjected to reverse-phase (RP)-HPLC separation to yield four fractions (CF1, CF2, CF3, and CF4). The CPH and RP-HPLC fractions were each tested at $1 \mathrm{mg} / \mathrm{mL}$ for ability to inhibit in vitro ACE and renin activities. CPH and the most active RP-HPLC fraction (CF3) were then used for enzyme inhibition kinetics assays followed by oral administration ( 200 and $30 \mathrm{mg} / \mathrm{kg}$ body weight for CPH and CF3, respectively) to SHRs and SBP measurements within $24 \mathrm{~h}$.

Results: The CPH, CF3, and CF4 had similar ACE-inhibitory activities of 84,85 , and $87 \%$, which were significantly $(p<0.05)$ higher than the values for CF1 $(69 \%)$ and CF2 $(79 \%)$. Conversely, the CF3 had the highest $(63 \%)$ renin-inhibitory activity $(p<0.05)$ when compared to $\mathrm{CPH}(43 \%), \mathrm{CF} 1(15 \%)$, and $\mathrm{CF} 4(44 \%)$. $\mathrm{CPH}$ and $\mathrm{CF} 3$ exhibited uncompetitive mode of ACE inhibition, whereas renin inhibition was non-competitive. Even at a 6.7-fold lower dosage, the CF3 significantly $(p<0.05)$ reduced $\mathrm{SBP}$ (maximum $-40.0 \mathrm{mmHg}$ ) better than $\mathrm{CPH}$ (maximum $-19.1 \mathrm{mmHg}$ ).

Conclusions: RP-HPLC fractionation led to enhanced antihypertensive effects of cod peptides, which may be due to a stronger renin-inhibitory activity.

Keywords: cod; protein hydrolysate; angiotensin I-converting enzyme; renin; enzyme inhibition kinetics; IC $C_{50}$; systolic blood pressure; spontaneously hypertensive rats

Received: 16 September 2015; Revised: 4 December 2015; Accepted: 6 December 20।5; Published: 28 December 2015

$\mathrm{H}$ ypertension is related to elevated blood pressure (BP) and is an independent yet controllable risk factor for cardiovascular events such as myocardial infarction, atherosclerosis, stroke, and heart failure (1). It has been estimated by the World Health Organization that by 2020 , heart disease and stroke will become the leading cause of death and disability globally (2). According to recent health reports, hypertension is considered a critical world health problem needing urgent attention and is estimated to affect up to 1.56 billion people by 2025 (3). In terms of actual numbers, hypertension accounts for approximately 17 million deaths a year, which is almost one-third of the total worldwide annual record of deaths (4). Physical activity and healthy diet could contribute to a significant reduction of about $30 \%$ in the morbidity and mortality that arise from hypertension (5). BP is controlled by the renin-angiotensin system in which renin produced from the kidney catalyzes the ratelimiting conversion of angiotensinogen to angiotensin I (AT-I), an inactive decapeptide (6). Angiotensin I-converting 
enzyme (ACE), which possesses a crucial role in $\mathrm{BP}$ regulation, then catalyzes the cleavage of the $\mathrm{C}$-terminal His-Leu dipeptide of the resulting AT-I into angiotensin II, a potent octapeptide vasopressor. ACE also extends its catalytic impact towards the inactivation of bradykinin and kallidin, the vasodilator peptides (1). Under nonhomeostatic or disease conditions, these catalytic actions of ACE can result in blood vessel wall stiffening and inability to relax following contraction, which, if not controlled, leads to hypertension. Synthetic ACE inhibitors (captopril, enalapril, lisinopril, etc.), renin inhibitor (aliskiren), and angiotensin receptor blockers are traditionally used to treat congestive heart failure and hypertension (7). However, there are reports of side effects such as cough, taste alterations, diarrhea, skin rashes, renal, and erectile dysfunction associated with these synthetic inhibitors which have resulted in an increased desire to find natural food-grade inhibitors (8-12). Natural food-based inhibitors that possess both renin- and ACE-inhibitory effects will usually be preferred as antihypertensive agents because this could provide more effective control of high BP, thus preventing hypertension. Currently, natural sources of renin and ACE inhibitors are being investigated as a milder but effective alternative for high BP control through protein hydrolysis using single strain or a mixture of enzymes or their sequential combination. To date, several food-grade peptide inhibitors with dual or multifunctional enzyme inhibitory properties from plant sources such as canola (13), rapeseed (14), and hemp seed (15) as well as animal sources such as chicken skin (16), cod (1), and catfish (17) have been produced. However, there is limited information on the mechanism of action and how chromatographic enrichment methods can be used to enhance potency of cod protein-derived peptides. Therefore, this work was based on the hypothesis that reverse-phase (RP)-HPLC separation of cod peptides can be used to isolate fractions with better in vitro and in vivo activities than the unfractionated protein hydrolysate. The aim of this work was to determine the reninand ACE-inhibitory activities of Atlantic cod fish (Gadus morhua) enzymatic protein hydrolysate in comparison with RP-HPLC peptide fractions. The most active peptide RP-HPLC fraction and unfractionated protein hydrolysate were then used for comparative kinetic studies of renin- and ACE-inhibitory mechanisms as well as systolic blood pressure (SBP)-reducing ability in spontaneously hypertensive rats (SHRs).

\section{Materials and methods}

\section{Materials}

The Renin Inhibitor Screening Assay Kit was purchased from Cayman Chemicals (Ann Arbor, MI, USA). Enzeco Trypsin-Chymotrypsin ${ }^{\circledR}$ 1:1 was obtained from Enzyme Development Corporation, New York, NY, USA. Pepsin, rabbit lung ACE, and $N$-[3-(2-furyl) acryloyl]-L-phenylalanyl-glycyl-glycine (FAPGG) were purchased from Sigma Chemicals (St. Louis, MO, USA). Methanol (HPLC grade), trifluoroacetic acid (TFA), 0.45- and 0.2-micron syringe filters, and all other analytical grade chemical reagents were obtained from Fisher Scientific (Oakville, ON, Canada).

\section{Preparation of cod protein hydrolysate}

A detailed description of the cod muscle preparation and protein hydrolysis has been previously described (18). Briefly, $50 \mathrm{~g}$ of minced boneless cod muscle was suspended in $200 \mathrm{~mL}$ distilled water followed by homogenization in a standard Waring Blender for $\sim 2 \mathrm{~min}$ at high speed. The homogenate was stored in the cold room overnight under constant stirring. The homogenate was then centrifuged at $7,000 \times g$ for $20 \mathrm{~min}$ at $4^{\circ} \mathrm{C}$ and the supernatant discarded while the pellet was collected and dispersed in $200 \mathrm{~mL}$ of distilled water. The protein dispersion was adjusted to $\mathrm{pH} 2.0$ with $2 \mathrm{~mol} / \mathrm{L} \mathrm{HCl}$ and pepsin $(600$ $1800 \mathrm{units} / \mathrm{mg}$ protein) added at $10,000 \mathrm{units} / \mathrm{g}$ fish protein. The enzyme-treated protein dispersion was incubated at $37^{\circ} \mathrm{C}$ for $12 \mathrm{~h}$ with continuous stirring and the digest adjusted to $\mathrm{pH} 7.8$ with $2 \mathrm{~mol} / \mathrm{L} \mathrm{NaOH}$ to irreversibly deactivate pepsin. A trypsin-chymotrypsin (Enzeco Trypsin-Chymotrypsin 1:1) mixture was then added at 1,000 units per mg fish protein for both components and digestion allowed to proceed for $4 \mathrm{~h}$ at $37^{\circ} \mathrm{C}$ with constant stirring. The digest was then boiled for $10 \mathrm{~min}$ to inactivate the enzymes, cooled to room temperature, centrifuged $\left(5,200 \times g\right.$ for $30 \mathrm{~min}$ at $\left.4^{\circ} \mathrm{C}\right)$, and the supernatant filtered through a Whatman \#2 qualitative filter paper. The filtrate was passed through a $1 \mathrm{kDa}$ molecular weight cut-off Prep/Scale Tangential Flow Filtration cartridge membrane ultrafiltration setup (Millipore Corporation, Bedford, MA, USA). The collected membrane permeate $(<1 \mathrm{kDa})$ was lyophilized as the cod protein hydrolysate $(\mathrm{CPH})$ and stored at $-20^{\circ} \mathrm{C}$.

\section{RP-HPLC separation of CPH}

CPH was fractionated using RP-HPLC on a Varian 940LC semi-preparative system according to a previously reported method (19). Briefly, the freeze-dried CPH was dissolved $(100 \mathrm{mg} / \mathrm{mL})$ in double-distilled water (DDW) that contained $0.1 \%$ TFA (solvent $\mathrm{A}$ ) and $4 \mathrm{~mL}$ (sequentially filtered through 0.45 and $0.2 \mu \mathrm{m}$ membrane disks) was injected onto a Phenomenex $\mathrm{C} 12$ preparative column $(21 \times 250 \mathrm{~mm})$. Fractions were eluted from the column at a flow rate of $10 \mathrm{~mL} / \mathrm{min}$ using a linear gradient of $0-100 \%$ solvent $\mathrm{B}$ (methanol that contained $0.1 \%$ TFA) over the course of $60 \mathrm{~min}$. Peptide elution was monitored at $220 \mathrm{~nm}$ and eluted peptides collected using an automated fraction collector at every $1 \mathrm{~min}$, which were then pooled into four fractions (CF1, CF2, CF3, and CF4) as previously reported (18). The pooled fractions were subjected to solvent evaporation in a rotary evaporator 
and the aqueous residues freeze-dried. Protein contents of $\mathrm{CPH}$ and its RP-HPLC peptide fractions were determined using the modified Lowry method (20).

\section{ACE inhibition assay}

Ability of cod peptides to inhibit in vitro ACE activity was determined using a spectrophotometric method with FAPGG as substrate (21). Briefly, $1 \mathrm{~mL}$ of $0.5 \mathrm{mmol} / \mathrm{L}$ FAPGG (dissolved in $50 \mathrm{mmol} / \mathrm{L}$ Tris- $\mathrm{HCl}$ buffer containing $300 \mathrm{mmol} / \mathrm{L} \mathrm{NaCl}, \mathrm{pH} 7.5$ ) was mixed with $20 \mu \mathrm{L} \mathrm{ACE}$ $(1 \mathrm{U} / \mathrm{mL}$, final activity of $20 \mathrm{mU}$ ) and $200 \mu \mathrm{L}$ sample dissolved in same buffer as the FAPGG. The rate of absorbance decrease at $345 \mathrm{~nm}$ was recorded for $2 \mathrm{~min}$ at room temperature. The buffer was used instead of sample solutions in the blank experiment. ACE activity was expressed as rate of reaction $(\Delta \mathrm{A} / \mathrm{min})$ and inhibitory activity was calculated as:

$$
\begin{aligned}
\operatorname{ACE} \text { inhibition }(\%)=\left[1-\Delta A \min ^{-1}{ }_{(\text {sample })} /\right. \\
\left.\Delta A \min ^{-1}{ }_{(\text {blank })}\right] \times 100
\end{aligned}
$$

where $\Delta A \min ^{-1}$ (sample) and $\Delta A \mathrm{~min}^{-1}$ (blank) are ACE activity in the presence and absence of inhibitory peptides, respectively. The concentration of peptide that inhibited ACE activity by $50 \%\left(\mathrm{IC}_{50}\right)$ was calculated by non-linear regression from a plot of percentage ACE inhibition versus four peptide concentrations $(0.125,0.25,0.5$, and $1.0 \mathrm{mg} /$ $\mathrm{mL}$ ). The kinetics of ACE inhibition was studied with $0.0625,0.125,0.25$, and $0.5 \mathrm{mmol} / \mathrm{L}$ substrate (FAPGG) concentrations. The mode of ACE inhibition was determined from the Lineweaver-Burk plots while kinetic parameters $\left(V_{\max }\right.$ and $\left.K_{\mathrm{m}}\right)$ were estimated from non-linear regression fit of the data to the Michaelis-Menten equation using GraphPad Prism version 5.0 (GraphPad Software, San Diego, CA, USA). Inhibition constant $\left(K_{\mathrm{i}}\right)$ was calculated as the $\mathrm{x}$-axis intercept from a plot of the slope of the Lineweaver-Burk lines against sample concentrations while catalytic efficiency (CE) was calculated from $V_{\text {max }} / K_{\mathrm{m}}$ ratio.

\section{Renin inhibition assay}

In vitro assay of human recombinant renin activity was conducted using the Renin Inhibitor Screening Assay Kit according to the method previously described (22). Briefly, sample was diluted in Tris- $\mathrm{HCl}$ buffer $(50 \mathrm{mmol} / \mathrm{L}, \mathrm{pH} 8.0$, containing $100 \mathrm{mmol} / \mathrm{L} \mathrm{NaCl}$ ), and prewarmed to $37^{\circ} \mathrm{C}$ prior to initiating the reaction. Before the reaction, 1) $20 \mu \mathrm{L}$ substrate, $160 \mu \mathrm{L}$ assay buffer, and $10 \mu \mathrm{L}$ DDW were added to the background wells; 2) $20 \mu \mathrm{L}$ substrate, $150 \mu \mathrm{L}$ assay buffer, and $10 \mu \mathrm{L} \mathrm{DDW}$ were added to the control wells; and 3) $20 \mu \mathrm{L}$ substrate, $150 \mu \mathrm{L}$ assay buffer, and $10 \mu \mathrm{L}$ sample were added to the inhibitor (sample) wells. The reaction was initiated by adding $10 \mu \mathrm{L}$ renin to the control and sample wells. The microplate was shaken for $10 \mathrm{~s}$ for proper mixing and incubated at $37^{\circ} \mathrm{C}$ for $15 \mathrm{~min}$; fluorescence intensity (FI) was then recorded at excitation and emission wavelengths of 340 and $490 \mathrm{~nm}$, respectively, using a fluorometric microplate reader (Spectra MAX Gemini, Molecular Devices, Sunnyvale, CA, USA). The percentage renin inhibition was calculated as follows:

$$
\begin{array}{r}
\text { Renin inhibition }(\%)=\left[1-\Delta F I U \min ^{-1}(\text { sample }) /\right. \\
\\
\left.\Delta F I U \min ^{-1} \text { (blank) }\right] \times 100
\end{array}
$$

where $\Delta F I U \min ^{-1}$ (sample) and $\Delta F I U \min ^{-1}$ (blank) are renin activity in the presence and absence of inhibitory peptides, respectively. $\mathrm{IC}_{50}$ was calculated by non-linear regression from a plot of percentage renin inhibition versus peptide concentrations $(0.125,0.25,0.5$, and $1.0 \mathrm{mg} / \mathrm{mL})$. The renin inhibition kinetics was conducted using $0.625,1.25$, $2.5,5$, and $10 \mu \mathrm{mol} / \mathrm{L}$ substrate concentrations in the absence and presence of samples, while kinetic parameters were calculated as described above for ACE.

Evaluation of antihypertensive activity of cod peptides in SHRs Animal experiments were carried out following the Canadian Council on Animal Care Ethics guidelines with a protocol approved by the University of Manitoba Animal Protocol and Management Review Committee. The male SHRs (Charles River Laboratories, Montreal, PQ) with $350-390 \mathrm{~g}$ body weight (bw) were kept in the Animal Housing Facility at the Richardson Centre for Functional Foods and Nutraceuticals, under a 12-h day and night cycle at $21^{\circ} \mathrm{C}$ and fed regular chow diet and tap water. The rats were divided into four groups $(\mathrm{CPH}, \mathrm{CF} 3$, captopril, and phosphate-buffered saline, $\mathrm{pH}$ 7.4) with six rats per group. The CPH $(200 \mathrm{mg} / \mathrm{kg}$ bw), CF3 (30 mg/kg bw), and captopril ( $10 \mathrm{mg} / \mathrm{kg} \mathrm{bw})$ were each dissolved in phosphate-buffered saline and administered to the SHRs by oral gavage followed by measurement of SBP over a 24-h period (at 2, 4, 6, 8, and 24h) using the tail-cuff method in slightly anesthetized rats as previously described (22). Prior to oral gavage, the baseline (time zero) SBP was determined; the SBP changes $(\triangle \mathrm{SBP}$, $\mathrm{mmHg}$ ) were determined by subtracting the baseline data from the values obtained at different time points.

\section{Statistical analysis}

All assays were conducted in triplicate and analyzed by one-way analysis of variance (ANOVA). The means were compared using Duncan's multiple range test and significant differences accepted at $p<0.05$.

\section{Results}

\section{Preparation of CPH and its RP-HPLC peptide fractions} Enzymatic hydrolysis of the cod fish muscles in this study using a combination of pepsin, trypsin, and chymotrypsin enzymes produced the $\mathrm{CPH}$, which was further subjected to RP-HPLC fractionation to obtain four distinct peptide fractions namely CF1, CF2, CF3, and CF4 (21). 
(a)

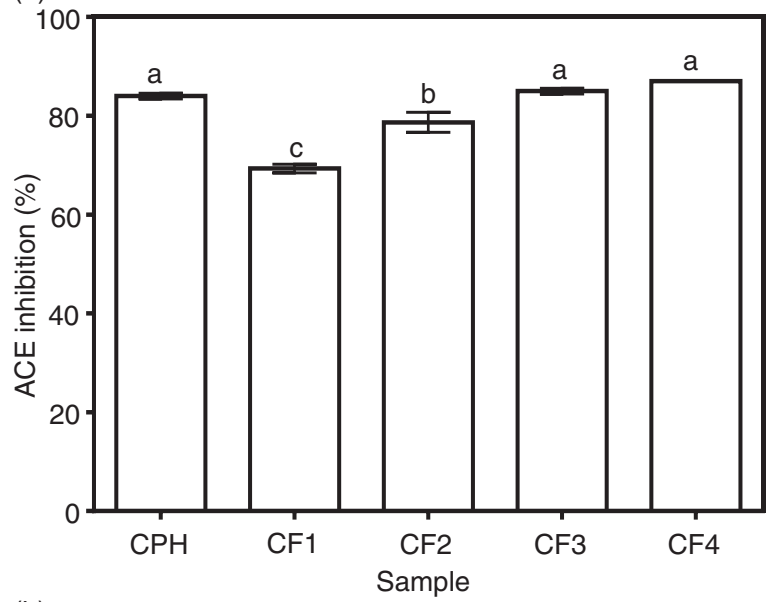

(b)

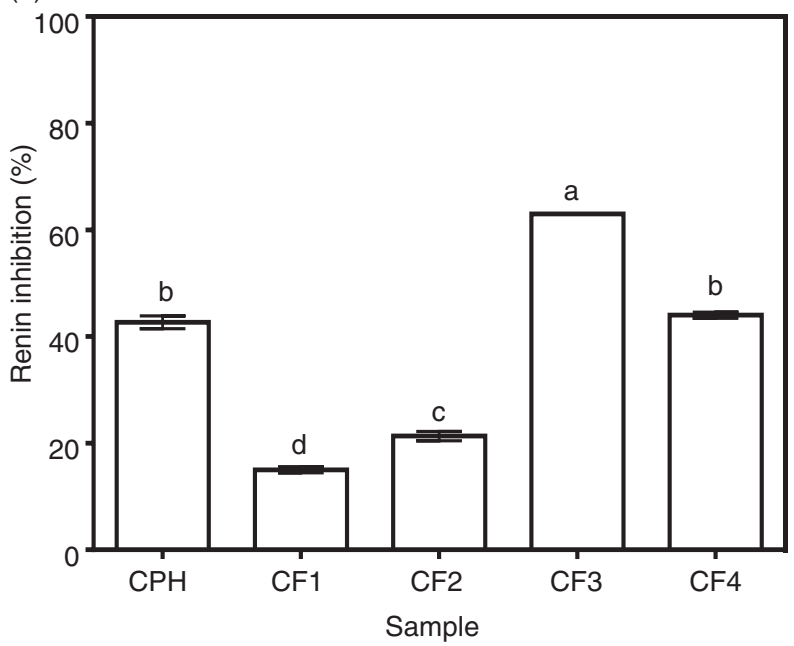

Fig. 1. In vitro (a) angiotensin I-converting enzyme (ACE) and (b) renin-inhibitory activities of cod protein hydrolysate $(\mathrm{CPH})$ and its RP-HPLC derived peptide fractions (CF1-CF4).

The percent protein content of CPH and its RP-HPLC peptide fractions (CF1, CF2, CF3, and CF4) were determined to be $58,40,96,91$, and $94 \%$, respectively.

\section{In vitro $A C E$ and renin-inhibitory activities}

$\mathrm{CPH}$ and its RP-HPLC fractions (CF1, CF2, CF3, and $\mathrm{CF} 4$ ) were subjected to in vitro testing for $\mathrm{ACE}$ - and renininhibitory activities and the results obtained are shown in Fig. 1a and b. The CPH and its RP-HPLC-derived fractions had ACE-inhibitory activities which ranged in magnitude from 69 to $87 \%$ at the tested level of $1 \mathrm{mg} / \mathrm{mL}$ protein concentration. The less hydrophobic (most hydrophilic) RP-HPLC cod peptide fractions, CF1 (69\%) and CF2 (79\%) showed good abilities to inhibit ACE; however, these abilities were significantly $(p<0.05)$ lower than the inhibitory levels exhibited by the most hydrophobic fractions CF3 (85\%) and CF4 (87\%). These high ACE activities of $\mathrm{CF} 3$ and $\mathrm{CF} 4$ are similar to the ACEinhibitory activity of the CPH (84\%).
Figure $1 \mathrm{~b}$ shows that the CF3 fraction had the highest while CF1 $(15 \%)$ had the least in vitro renin-inhibitory activity. CPH (43\% renin-inhibitory activity) fractionation significantly $(p<0.05)$ improved renin-inhibitory activity only in CF3 but not in CF1, CF2, and CF4 which exhibited renin-inhibitory activities of 15,21 , and $44 \%$, respectively. Peptide fraction hydrophobic character also seemed to play a role in renin inhibition just as observed for ACE inhibition. This is because the less hydrophobic CF1 and CF2 had lower renin-inhibitory values than the more hydrophobic CF3 and CF4. As expected, the renin inhibition potency of cod peptides $(15-63 \%)$ was generally lower than that of ACE inhibition $(69-87 \%)$. Based on the above in vitro bioactivity results, the most active fraction against both ACE and renin $(\mathrm{CF} 3)$ was chosen for further comparison with $\mathrm{CPH}$ in terms of $\mathrm{IC}_{50}$ values, enzyme inhibition kinetics, and SBP-lowering ability in SHRs. The renin $\mathrm{IC}_{50}$ values as shown Fig. 2 confirms the significantly $(p<0.05)$ stronger ACE- and renin-inhibitory properties of $\mathrm{CF} 3$ when compared to $\mathrm{CPH}$.

\section{ACE-inhibitory kinetics of CPH and its RP-HPLC peptide fraction (CF3)}

In this study, we used Lineweaver-Burk plots to evaluate both the ACE and renin modes of inhibition of the most active $\mathrm{CF} 3$ fraction in comparison with the unfractionated hydrolysate $(\mathrm{CPH})$. The double reciprocal plots for ACE-catalyzed reactions in the absence and presence of these cod peptides as shown in Fig. 3a and b for $\mathrm{CPH}$ and $\mathrm{CF} 3$, respectively, indicate a mostly uncompetitive type of inhibition. This is because the lines crossed each of the $\mathrm{y}$ - and $\mathrm{x}$-axis at different points. Therefore, ACEinhibitory $K_{\mathrm{m}}$ and $V_{\max }$ values for both $\mathrm{CPH}$ and $\mathrm{CF} 3$ were lower in the presence of peptides (Table 1). CE was also lower in the presence of $\mathrm{CPH}$ and $\mathrm{CF} 3$ peptides. The inhibition constant $\left(K_{\mathrm{i}}\right)$, which is a measure of the

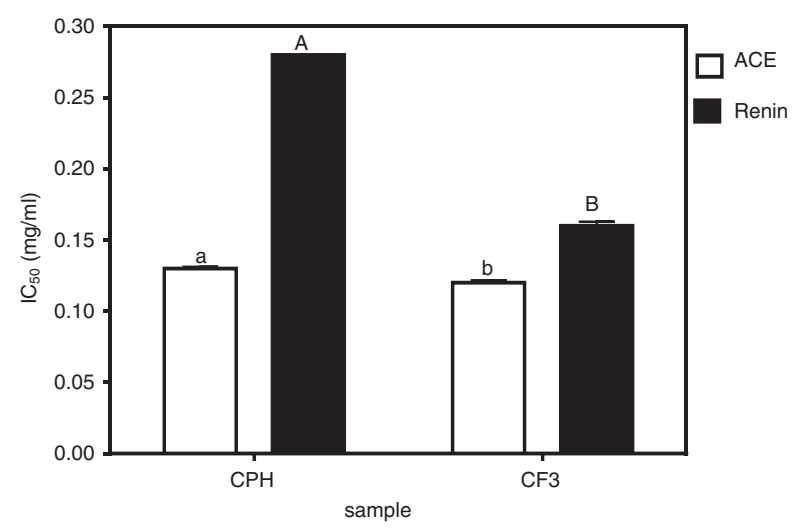

Fig. 2. Peptide inhibitory concentrations of cod protein hydrolysate $(\mathrm{CPH})$ and its most active RP-HPLC peptide fraction $3(\mathrm{CF} 3)$ that reduced $50 \%$ of enzyme activity $\left(\mathrm{IC}_{50}\right)$. 
(a)

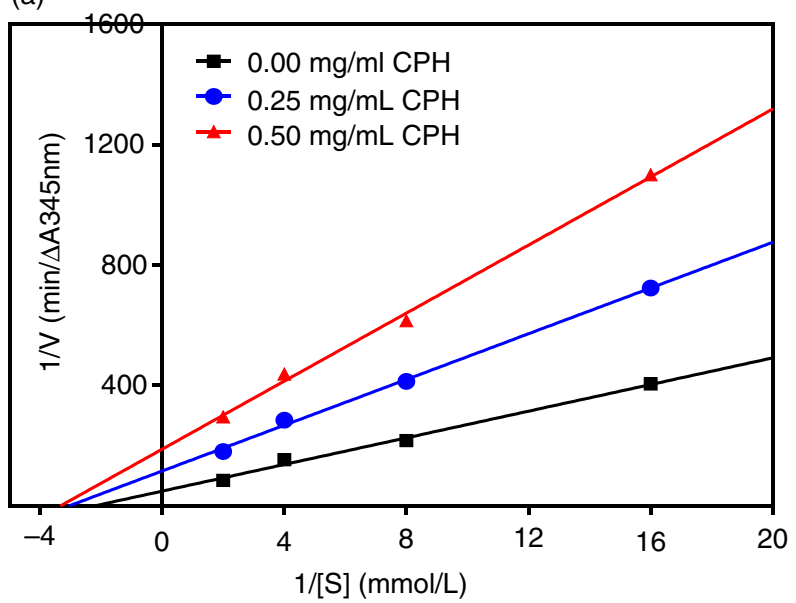

(b)

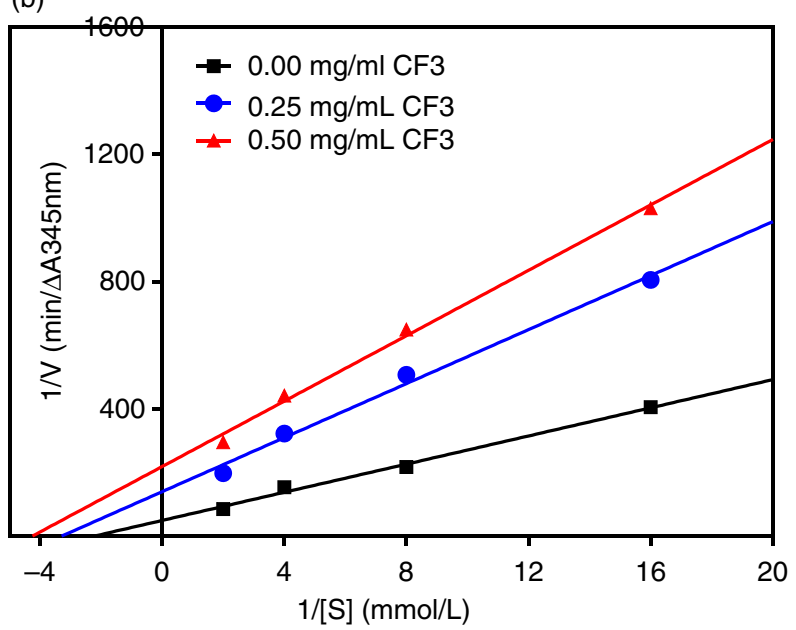

Fig. 3. Lineweaver-Burk plots of angiotensin I-converting enzyme (ACE) inhibition at different peptide concentrations: (a) cod protein hydrolysate $(\mathrm{CPH})$ and (b) most active RPHPLC peptide fraction $3(\mathrm{CF} 3)$.

inhibitor binding strength to ACE enzyme indicates that the $\mathrm{CPH}$ peptides $(0.263 \mathrm{mg} / \mathrm{mL})$ bind stronger than the CF3 peptides $0.394 \mathrm{mg} / \mathrm{mL}$ ).

\section{Renin-inhibitory kinetics of CPH and CF3 RP-HPLC peptide} fraction

In contrast to ACE inhibition kinetics, Fig. 4a and b, respectively, showed that the $\mathrm{CPH}$ and $\mathrm{CF} 3$ exhibited a non-competitive mode of renin inhibition because the lines intersect the $\mathrm{x}$-axis at approximately the same point. Non-competitive renin inhibition is typically exhibited with observed decreases in $V_{\max }$ but with similar $K_{\mathrm{m}}$ values (Table 1). The CE and $K_{\mathrm{i}}$ of the renin enzyme both decreased dose-dependently, suggesting that as the inhibitor concentration was increased the inhibitor binding affinity and inhibition efficiency for the enzyme was increased resulting in a reduction in the enzyme activity due to conformational changes.

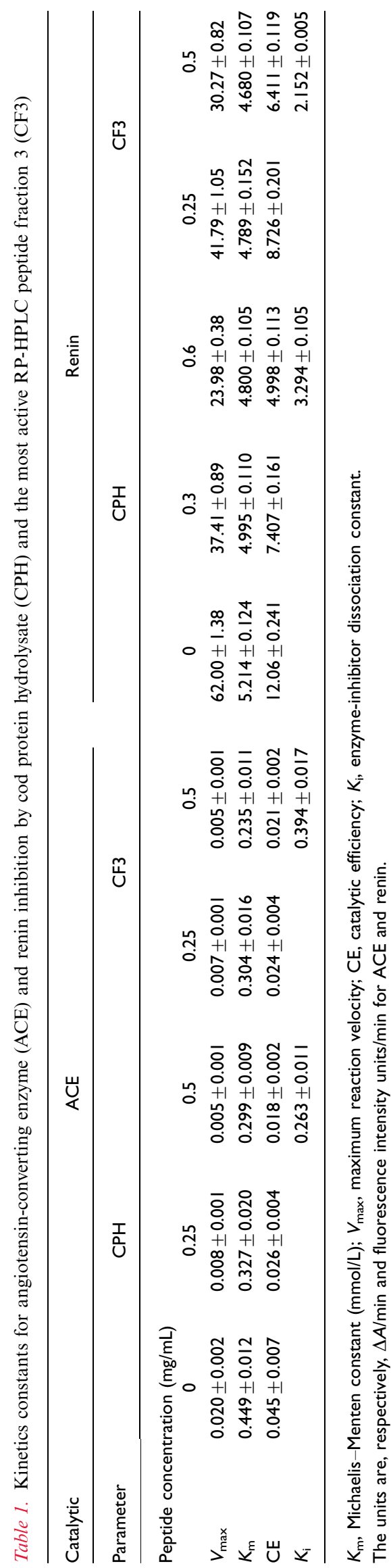


(a)

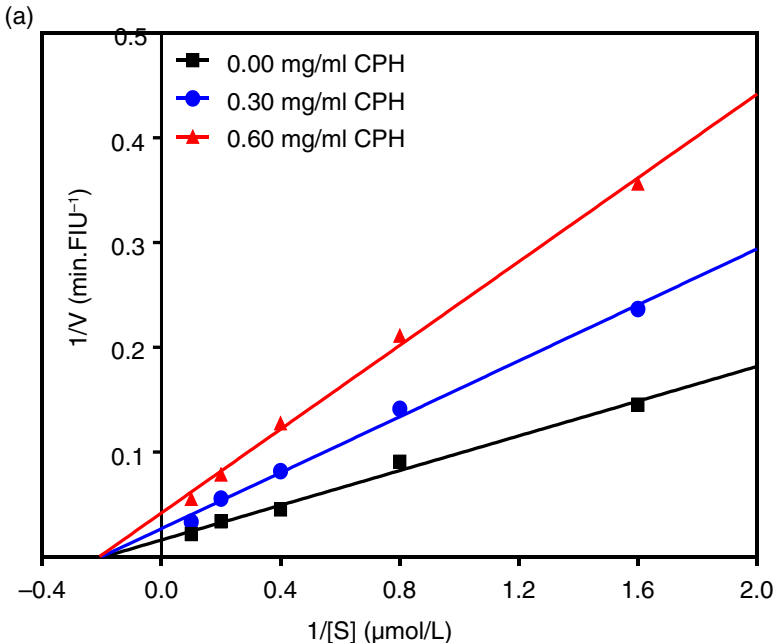

(b)

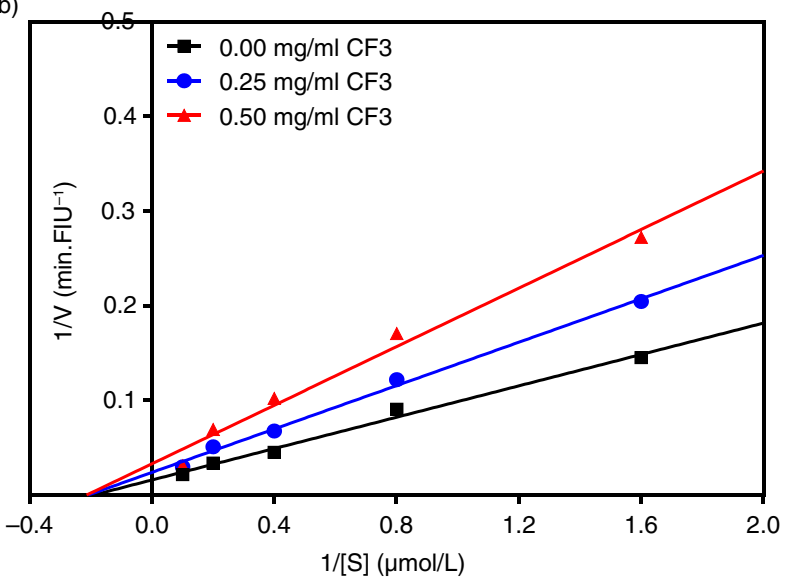

Fig. 4. Lineweaver-Burk plots of human recombinant renin inhibition at different peptide concentrations: (a) cod protein hydrolysate $(\mathrm{CPH})$ and (b) most active RP-HPLC peptide fraction $3(\mathrm{CF} 3)$.

\section{BP lowering effect of CPH and CF3 in SHRs}

In order to confirm the potential BP-reducing effects of cod peptides as observed during the in vitro tests, $\mathrm{CPH}$ and its most active RP-HPLC CF3 were orally administered to SHRs. As shown in Fig. 5, administration of CF3 $(30 \mathrm{mg} / \mathrm{kg}$ bw) resulted in significant decreases in SBP at different time points when compared to saline (the negative control). The maximum SBP decrease due to $\mathrm{CF} 3$ was $-40 \mathrm{mmHg}$ after $2 \mathrm{~h}$. Even though the hypotensive effect of $\mathrm{CF} 3$ gradually reduced with time, it was still significantly maintained up until $24 \mathrm{~h}(-12 \mathrm{mmHg})$ post-administration. Oral administration of $\mathrm{CPH}$ at a higher dose of $200 \mathrm{mg} / \mathrm{kg}$ bw led to a maximum SBP decrease of $-19.1 \mathrm{mmHg}$ also after $2 \mathrm{~h}$, which is significantly $(p<0.05)$ weaker than the $30 \mathrm{mg} / \mathrm{kg}$ bw lower dose of CF3. Moreover, persistence of the $\mathrm{CPH}$ was also weaker with a $-5.0 \mathrm{mmHg}$ effect after $24 \mathrm{~h}$ post-administration when compared to $-12 \mathrm{mmHg}$ for CF3.

\section{Discussion}

\section{Protein content}

The low protein content of the $\mathrm{CPH}$ may be attributed mainly to the presence of non-peptide components, especially salt, that were formed during proteolysis when $\mathrm{NaOH}$ was added to neutralize the protons released by the proteases. Therefore, for CF1, the low protein content can be attributed to co-elution of these salts with peptides. This is because the polar salts bind poorly to the hydrophobic reverse-phase column and will co-elute with early eluting peptides in CF1. The CF2-CF4 peptides that eluted later will contain less salt and more protein because most of the salts would have eluted with CF1. Similar results showing that the initial eluted fractions from hydrophobic chromatographic column exhibited low protein contents while later-eluting fractions had higher values have previously been reported for hemp seed protein hydrolysate fractions separated by RP-HPLC (23). Therefore, because peptide activity is the focus of this work, all experiments were conducted based on protein weight of the samples.

\section{$A C E$ and renin inhibitions}

Because all the samples contain a mixture of peptides, enzyme inhibitory activities of $\mathrm{CPH}$ and $\mathrm{CF} 1-\mathrm{CF} 4$ may perhaps be attributed to a synergistic effect of active cod peptides. In this respect, fractionation led to reduced peptide synergy in CF1 $(69 \%)$ and CF2 $(79 \%)$ because of the significantly $(p<0.05)$ lower ACE and renin-inhibitory values when compared to $\mathrm{CPH}, \mathrm{CF} 3$, and $\mathrm{CF} 4$. However, the reduced $\mathrm{ACE}$ and renin-inhibitory activities could also be due to interference from salts because CF1 and CF2 had lower protein contents and hence higher levels of nonpeptide components. The results are similar to a previous work showing reduced ACE-inhibitory efficiency of rapeseed peptide fractions that had lower protein contents (14). For renin inhibition, fractionation effectively increased peptide inhibition only for $\mathrm{CF} 3$, which indicates the presence of peptides with strongest binding or synergistic activities. Thus, the ability of the cod peptides to inhibit both ACE and renin activities could be used as an effective tool to modulate the renin-angiotensin system in order to treat or prevent hypertension. Generally, ACE-inhibitory values were higher than renin-inhibitory values, which indicate that the cod peptides have stronger affinity for ACE. However, it should be noted that the two enzyme assay methods are different and direct comparison may not be possible. The renin- and ACE-inhibitory activities of cod peptides are in agreement with previous reports on food-based protein-derived peptides from different sources with multifunctional inhibitory activities against these vasoactive enzymes (14-16).

The $\mathrm{IC}_{50}$ values can also be used to evaluate potential potency and smaller values are preferred because the sample will be more effective at lower doses than samples with higher values. Therefore, the CF3 will be preferred as 


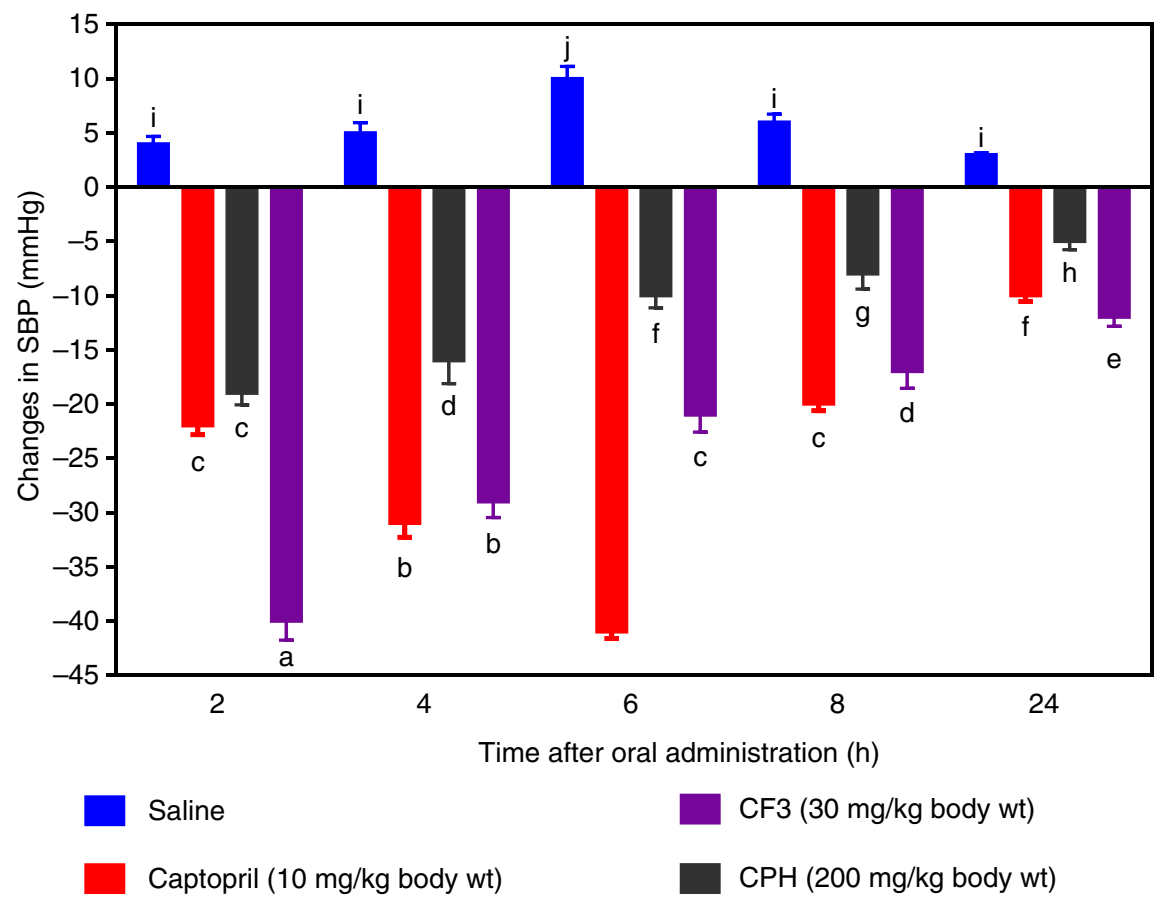

Fig. 5. Time dependent changes in systolic blood pressure (SBP) of spontaneously hypertensive rats administered cod protein hydrolysate $(\mathrm{CPH})$ and the most active RP-HPLC peptide fraction 3 (CF3).

an inhibitory agent when compared to $\mathrm{CPH}$ based on their $\mathrm{ACE}$ and renin-inhibitory $\mathrm{IC}_{50}$ values. The $\mathrm{CPH}$ ACEinhibitory $\mathrm{IC}_{50}$ value obtained in this work $(0.13 \mathrm{mg} / \mathrm{mL})$ is higher (weaker potency) than previously reported F3 permeates of skin $\left(\mathrm{IC}_{50}=0.003 \mathrm{mg} / \mathrm{mL}\right)$ and bone $\left(\mathrm{IC}_{50}=0.013 \mathrm{mg} / \mathrm{mL}\right)$ gelatins of Pangasius catfish (17), dried bonito $\left(\mathrm{IC}_{50}=0.029 \mathrm{mg} / \mathrm{mL}\right)(24)$, and crude thermolysin hydrolysates from $\alpha$-zein $\left(\mathrm{IC}_{50}=0.021 \mathrm{mg} / \mathrm{mL}\right)$ (25). However, the $\mathrm{CPH}$ and $\mathrm{CF} 3$ have lower (stronger potency) ACE-inhibitory $\mathrm{IC}_{50}$ values than those reported for ex vivo myofibrillar digest and sarcoplasmic duodenal $\left(\mathrm{IC}_{50}=1.06\right.$ and $2.16 \mathrm{mg} / \mathrm{mL}$, respectively) (26), sea cucumber gelatin $\left(\mathrm{IC}_{50}=0.35 \mathrm{mg} / \mathrm{mL}\right)(27)$, whole bovine casein $(0.684 \mathrm{mg} / \mathrm{mL})(28)$, and porcine $\left(\mathrm{IC}_{50}=1.53 \mathrm{mg} /\right.$ $\mathrm{mL}$ ) (29) protein hydrolysates. The $\mathrm{CPH}$ and $\mathrm{CF} 3$ also have lower ACE-inhibitory $\mathrm{IC}_{50}$ values than the F3-I $\left(\mathrm{IC}_{50}=0.62 \mathrm{mg} / \mathrm{mL}\right)$ and F3-II $\left(\mathrm{IC}_{50}=1.44 \mathrm{mg} / \mathrm{mL}\right)$ peptides of the second FPLC purification step of alcalasederived seaweed pipefish muscle protein hydrolysate (30). In general the ACE-inhibitory $\mathrm{IC}_{50}$ values for food protein peptides are higher (lower potency) than the 0.00039$0.0085 \mathrm{mg} / \mathrm{mL}$ range reported for captopril, the antihypertensive drug (31). There are no available renin $\mathrm{IC}_{50}$ values for fish or marine peptides in literature to make fair comparison with our current results for cod peptides in this study. However, the renin-inhibitory $\mathrm{IC}_{50}$ values for $\mathrm{CPH}(0.28 \mathrm{mg} / \mathrm{mL})$ and $\mathrm{CF} 3(0.16 \mathrm{mg} / \mathrm{mL})$ are lower than the $0.81-1.89 \mathrm{mg} / \mathrm{mL}$ and $1.4-2.7 \mathrm{mg} / \mathrm{mL}$ values reported for hemp seed (22) and flaxseed (32) protein hydrolysates, respectively. The observed differences in $\mathrm{IC}_{50}$ values could be due to variations in peptide components, which would dictate strength of the synergistic interactions that are responsible for enzyme inhibition. Similar to the present results, the renin-inhibitory $\mathrm{IC}_{50}$ values obtained for chicken skin protein hydrolysates were also found to be higher than the ACE-inhibitory $\mathrm{IC}_{50}$ values (16), which supports literature evidence indicating renin as a more difficult enzyme to inhibit in comparison to ACE.

\section{Enzyme inhibition kinetics}

It is vital to study the inhibitory kinetic properties of ACE and renin inhibitors because this helps reveal the possible mechanisms by which peptides are able to act as antihypertensive agents. ACE inhibition by $\mathrm{CPH}$ and CF3 was through uncompetitive mode, which means that the peptides were bound to the enzyme-substrate complex to form inhibitory complexes with reduced capacity to yield products. As evident in Table 1, binding of $\mathrm{CPH}$ and $\mathrm{CF} 3$ to $\mathrm{ACE}$ led to catalytic activity reduction, which is manifested as $V_{\max }$ decreases in proportion to peptide concentrations. The decreased ACE catalytic activity (or catalytic efficiency) in the presence of these peptides could be attributed to enzyme conformational rearrangement that reduced ability of the active site to accommodate the substrate. The $K_{\mathrm{m}}$ value in absence of an inhibitor $(0.449 \mathrm{mmol} / \mathrm{L}$ FAPGG $)$ in this study is slightly higher than the previously reported value of $0.306 \mathrm{mmol} / \mathrm{L}$ for flaxseed protein hydrolysate (32), but lower than the $0.6639 \mathrm{mmol} / \mathrm{L}$ for hemp seed protein hydrolysate (22). $K_{\mathrm{i}}$ is a measure of peptide affinity for the target enzyme 
and lower values indicate stronger binding potential than higher values. Table 1 shows higher ACE-binding ability by $\mathrm{CPH}$ than $\mathrm{CF} 3$ with lower and higher $K_{\mathrm{i}}$ values, respectively, though this trend did not translate to better inhibition by $\mathrm{CPH}$. However, the $K_{\mathrm{i}}$ values for $\mathrm{CPH}$ and $\mathrm{CF} 3$ recorded in this study are lower than some of the values (up to $4.74 \mathrm{mg} / \mathrm{mL}$ ) reported for the hemp seed protein hydrolysate fractions (22). In contrast, the $K_{\mathrm{i}}$ values are higher than the $0.044-0.051 \mathrm{mg} / \mathrm{mL}$ reported for chicken skin protein hydrolysate and peptide fractions (33).

Contrary to the ACE inhibition pattern, the $\mathrm{CPH}$ and CF3 inhibited renin activity mostly through a noncompetitive mode. This implies that the inhibitor can achieve its inhibitory effects by binding to both the free renin and renin-substrate complex. In either case the enzyme-peptide interactions reduce enzyme affinity for substrate and hence less conversion to products as evident by the decreased $V_{\max }$ values shown in Table 1 . The non-competitive mechanism of renin inhibition by cod peptides obtained in this study is different from the uncompetitive and mixed-type modes reported for flaxseed cationic (32) and hemp seed protein hydrolysate peptides, respectively (22).

\section{Antihypertensive effects in SHRs}

The CF3 peptide demonstrated an excellent potential antihypertensive agent because of the fast-acting BP-lowering effect in SHRs within the first $2 \mathrm{~h}$ after oral administration and the persistent effect observed after $24 \mathrm{~h}$. The results are consistent with the higher renin-inhibitory activity of $\mathrm{CF} 3$ when compared to $\mathrm{CPH}$ (Figs. $1 \mathrm{~b}$ and 2). On a weight basis, the CF3 was about 12 times as potent as the $\mathrm{CPH}$ in BP-reducing potency. The results suggest that $\mathrm{CPH}$ and CF3 peptides were absorbed into the blood from the SHR gastrointestinal tract but the CF3 may have been absorbed more quickly. It is also possible that the CF3 peptides had stronger inhibitory effects during in vivo interactions with $\mathrm{ACE}$ and renin. The persistent BP-reducing effect of CF3 suggests that the peptides were perhaps more resistant to in vivo proteases than the $\mathrm{CPH}$ peptides. It is difficult to compare the $\mathrm{CF} 3$ data with literature values because of the differences in dosage administered to the SHR. For example, 10 and $100 \mathrm{mg} / \mathrm{kg}$ bw bovine casein hydrolysate produced -28 and $-42 \mathrm{mmHg}$ SBP reductions, respectively, $2 \mathrm{~h}$ after oral administration to SHRs (34). In contrast, a peptic oyster digest had weaker BP-reducing effects with $-16 \mathrm{mmHg}$ reduction after $4 \mathrm{~h}$ (35). Translating the $30 \mathrm{mg} / \mathrm{kg}$ bw CF3 dose which caused a $-40.0 \mathrm{mmHg} \mathrm{BP}$ reduction in the SHRs indicates a potentially effective dose of only $350 \mathrm{mg} /$ day for a $70 \mathrm{~kg}$ human being (36). Because the protein hydrolysate was obtained using pepsin and trypsin digestions, the nutritional implication could mean potential cardiovascular health benefits of cod protein consumption. This is supported by the work of Yahia et al. (37) who reported that addition of $20 \%$ (w/w) unhydrolyzed fish protein to the diet resulted in $-31 \mathrm{mmHg}$ reduction in SHR SBP after a 2-month feeding study. However, because the source of fish protein was not indicated, direct comparison with our current work is not possible.

In conclusion, although in vitro assays provide rapid assessment of bioactive potential of peptides, the use of physiologically relevant animal disease models provides for a realistic estimation of applicability to human disease conditions. Hence, the positive relationship between in vitro and in vivo data in this work provides a scientific basis to use these peptides in future human intervention trials to determine potential therapeutic utility. Although the expected human dose will be several times more than that of a drug, the lack of substantial negative side effects during peptide use as reported by several researchers should make the cod peptides attractive antihypertensive options.

\section{Authors' contributions}

TG and REA designed the study and critically revised the manuscript. ATG, IDN, FH, and TN carried out the experiments. ATG also drafted the manuscript.

\section{Conflict of interest and funding}

The work was funded in part through a Strategic Grant awarded to TG by the Natural Sciences and Engineering Research Council (NSERC) of Canada. REA's research program is funded in part by an NSERC Discovery grant award. Authors declare no conflict of interest.

\section{References}

1. Jensen IJ, Eysturskarð J, Madetoja M, Eilertsen K-E. The potential of cod hydrolyzate to inhibit blood pressure in spontaneously hypertensive rats. Nutr Res 2014; 34: 168-73.

2. Himaya SWA, Ngo DH, Ryu B, Kim SK. An active peptide purified from gastrointestinal enzyme hydrolysate of Pacific cod skin gelatin attenuates angiotensin-1 converting enzyme (ACE) activity and cellular oxidative stress. Food Chem 2012; 132: 1872-82.

3. Kearney PM, Whelton M, Reynolds K, Muntner P, Whelton PK, He J. Global burden of hypertension: analysis of worldwide data. Lancet 2005; 365: 217-23.

4. Amado IR, Vázquez JA, González P, Esteban-Fernández D, Carrera M, Piñeiro C. Identification of the major ACEinhibitory peptides produced by enzymatic hydrolysis of a protein concentrate from cuttlefish wastewater. Marine Drugs 2014; 12: 1390-405.

5. WHO. World Health Day 2013. Available from: http://www.emro. who.int/world-health-days/2013/nutrition-hypertension-factsheetwhd-2013.html [cited 4 December 2015].

6. Aluko RE. Antihypertensive peptides from food proteins. Annu Rev Food Sci Technol 2015; 6: 235-62.

7. Harel Z, Gilbert C, Wald R, Bell C, Perl J, Juurlink D, et al. The effect of combination treatment with aliskiren and blockers of the renin-angiotensin system on hyperkalaemia and acute kidney injury: systematic review and meta-analysis. BMJ 2012; 344: e42. 
8. Fogari R, Zoppi A, Poletti L, Marasi G, Mugellini A, Corradi L. Sexual activity in hypertensive men treated with valsartan or carvediol: a crossover study. Am J Hypertens 2001; 14: 27-31.

9. Blumentals WA, Brown RR, Gomez-Caminero A. Antihypertensive treatment and erectile dysfunction in a cohort of type II diabetes patients. Int J Impot Res 2003; 15: 314-17.

10. Abassi Z, Winaver J, Feuerstein GZ. The biochemical pharmacology of renin inhibitors: implications for translational medicine in hypertension, diabetic nephropathy and heart failure: expectations and reality. Biochem Pharmacol 2009; 78: 933-40.

11. Gunkel AR, Thurner KH, Kanonier G, Sprinzl GM, Thumfart WF. Angioneurotic edema as a reaction to angiotensin-converting enzyme inhibitors. Am J Otolaryngol 1996; 17: 87-91.

12. Tenenbaum A, Grossman E, Shemesh J, Fisman EZ, Nosrati I, Motro M. Intermediate but not low doses of aspirin can suppress angiotensin-converting enzyme inhibitor-induced cough. Am J Hypertens 2000; 13: 776-82.

13. Alashi AM, Blanchard CL, Mailer RJ, Agboola SO, Mawson AJ, He R, et al. Blood pressure lowering effects of Australian canola protein hydrolysates in spontaneously hypertensive rats. Food Res Int 2014; 55: 281-7.

14. He R, Malomo SA, Alashi A, Girgih AT, Ju X, Aluko RE. Purification and hypotensive activity of rapeseed proteinderived renin and angiotensin converting enzyme inhibitory peptides. J Funct Foods 2013; 5: 781-9.

15. Girgih AT, He R, Malomo S, Offengenden M, Wu J, Aluko RE. Structural and functional characterization of hemp seed (Cannabis sativa L.) protein-derived antioxidant and antihypertensive peptides. J Funct Foods 2014; 6: 384-94.

16. Onuh JO, Girgih AT, Aluko RE, Aliani M. Inhibitions of renin and angiotensin converting enzyme activities by enzymatic chicken skin protein hydrolysates. Food Res Int 2013; 53: 260-7.

17. Mahmoodani F, Ghassem M, Babji AS, Yusop SM, Khosrokhavar R. ACE inhibitory activity of pangasius catfish (Pangasius sutchi) skin and bone gelatin hydrolysate. J Food Sci Technol 2014; 51: 1847-56.

18. Girgih AT, He R, Hasan FM, Udenigwe CC, Gill TA, Aluko $\mathrm{RE}$. Evaluation of the in vitro antioxidant properties of a Cod (Gadus morhua) protein hydrolysate and peptide fractions. Food Chem 2015; 173: 652-9.

19. Pownall TL, Udenigwe CC, Aluko RE. Amino acid composition and antioxidant properties of pea seed (Pisum sativum L.) enzymatic protein hydrolysate fractions. J Agric Food Chem 2010; 58: 4712-18.

20. Markwell MAK, Haas SM, Bieber LL, Tolbert NE. A modification of the Lowry procedure to simplify protein determination in membrane and lipoprotein samples. Anal Biochem 1978; 87: 206-10.

21. Holmquist B, Bünning P, Riordan JF. A continuous spectrophotometric assay for angiotensin converting enzyme. Anal Biochem 1979; 95: 540-8.

22. Girgih AT, Udenigwe CC, Li H, Adebiyi AP, Aluko RE. Kinetics of enzyme inhibition and antihypertensive effects of hemp seed (Cannabis sativa L.) protein hydrolysates. J Am Oil Chem Soc 2011; 88: 1767-74.

23. Girgih AT, Udenigwe CC, Aluko RE. Reverse-phase HPLC separation of hemp seed (Cannabis sativa L.) protein hydrolysate produced peptide fractions with enhanced antioxidant capacity. Plant Foods Hum Nutr 2013; 68: 39-46.
24. Fujita H, Yokoyama K, Yasumoto R, Yoshikawa M. Antihypertensive effect of thermolysin digest of dried bonito in spontaneously hypertensive rat. Clin Exp Pharmacol Physiol 1995; 22: S304-5.

25. Miyoshi S, Kaneko T, Ishikawa H, Tanaka H, Maruyama S. Production of bioactive peptides from corn endosperm proteins by some proteases. Ann N Y Acad Sci 1995; 750: 429-31.

26. Darewicz M, Borawska J, Vegarud GE, Minkiewicz P, Iwaniak A. Angiotensin I-converting enzyme (ACE) inhibitory activity and ACE inhibitory peptides of salmon (Salmo salar) protein hydrolysates obtained by human and porcine gastrointestinal enzymes. Int J Mol Sci 2014; 15: 14077-101.

27. Zhao X, Zhao Y, Li B, Liu Z, Dong S, Zeng M. Antihypertensive effect and purification of an ACE inhibitory peptide from sea cucumber gelatin hydrolysate. Process Biochem 2007; 42: 1586-91.

28. Jiang Z, Tian B, Brodkorb A, Huo G. Production, analysis and in vivo evaluation of novel angiotensin-I-converting enzyme inhibitory peptides from bovine casein. Food Chem 2010; 123: 779-86.

29. Deng H, Zheng J, Zhang F, Wang Y, Kan J. Isolation of angiotensin I-converting enzyme inhibitor from pepsin hydrolysate of porcine hemoglobin. Eur Food Res Technol 2014; 239: 933-40.

30. Wijesekara I, Qian ZJ, Ryu B, Ngo DH, Kim SK. Purification and identification of antihypertensive peptides from seaweed pipefish (Syngnathus schlegeli) muscle protein hydrolysate. Food Res Int 2011; 44: 703-7.

31. Henda YB, Labidi A, Arnaudin I, Bridiau N, Delatouche R, Maugard $\mathrm{T}$, et al. Measuring angiotensin-I converting enzyme inhibitory activity by micro plate assays: comparison using marine cryptides and tentative threshold determinations with captopril and losartan. J Agric Food Chem 2013; 61: 10685-90.

32. Udenigwe CC, Lin YS, Hou WC, Aluko RE. Kinetics of the inhibition of renin and angiotensin I-converting enzyme by flaxseed protein hydrolysate fractions. J Funct Foods 2009; 1: 199-207.

33. Onuh JO, Girgih AT, Malomo SA, Aluko RE, Aliani M. Kinetics of in vitro renin and angiotensin converting enzyme inhibition by chicken skin protein hydrolysates and their blood pressure lowering effects in spontaneously hypertensive rats. J Funct Foods 2015; 14: 133-43.

34. Yamada A, Sakurai T, Ochi D, Mitsuyama E, Yamauchi K, Abe F. Novel angiotensin I-converting enzyme inhibitory peptide from bovine casein. Food Chem 2013; 141: 3781-9.

35. Wang J, Hu J, Cui J, Bai X, Du Y, Yuji M, et al. Purification and identification of a ACE inhibitory peptide from oyster proteins hydrolysate and the antihypertensive effect of hydrolysate in spontaneously hypertensive rats. Food Chem 2008; 111: 302-8.

36. Reagan-Shaw S, Nihal M, Ahmad N. Dose translation from animal to human studies revisited. FASEB J 2007; 22: 659-61.

37. Yahia DA, Madani S, Prost E, Prost J, Bouchenak M, Belleville J. Tissue antioxidant status differs in spontaneously hypertensive rats fed fish protein or casein. J Nutr 2003; 133: 479-82.

\section{*Rotimi E. Aluko}

Department of Human Nutritional Sciences

University of Manitoba

Winnipeg, Canada MB R3T 2N2

Email: rotimi.aluko@umanitoba.ca 